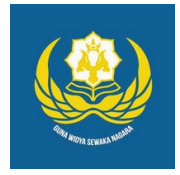

Jurnal Analogi Hukum

Journal Homepage: https://ejournal.warmadewa.ac.id/index.php/analogihukum

\title{
Analisis Tentang Pencemaran Nama Baik dan Penyalahgunaan Hak Kebebasan Berpendapat di Media Sosial
}

\author{
I Made Vidi Jayananda*, I Nyoman Gede Sugiartha dan I Made Minggu Widyantara \\ Fakultas Hukum, Universitas Warmadewa, Denpasar, Bali-Indonesia \\ *vidijayananda39@gmail.com
}

\begin{abstract}
How To Cite:
Jayananda, I. M. V., Sugiartha, I. N. G., \& Widyantara, I. M. M. (2021). Pemberian Analisis Tentang Pencemaran Nama Baik dan Penyalahgunaan Hak Kebebasan Berpendapat di Media Sosial. Jurnal Analogi Hukum. 3 (2). 261-265. Doi: https:// doi.org/10.22225/ah.3.2.2021.261-265
\end{abstract}

\begin{abstract}
Freedom of opinion, especially in social media, is currently widely misinterpreted and abused by the community, because in the use of the right to freedom of opinion, the community has taken many actions which fall into insult, accusations without evidence and commit defamation which cause harm to certain individuals. The problems in this research are How are criminal law regulations and violations of the abuse of the right to freedom of expression in social media and how criminal sanctions against criminal acts of defamation are under the guise of freedom of opinion. The research method used is normative legal research. Source of primary and secondary legal materials. This research concludes that freedom of opinion is not absolute freedom, but in opinion must be in accordance with ethics and norms in society and in accordance with legal regulations without harming any party.
\end{abstract}

Keywords: Rules; Freedom of Opinion; Crime.

\begin{abstract}
Abstrak - Kebebasan dalam berpendapat terutama di media social saat ini banyak disalah artikan dan disalahgunakan oleh masyarakat, karena dalam penggunaan hak kebebasan berpendapat tersebut masyarahat banyak melakukan tindakan yang jatuhnya menjadi penghinaan, tuduhan tanpa disertai bukti dan melakukan pencemaran nama baik yang menimbulkan kerugian terhadap individu tertentu. Permasalahan dalam penelitian ini adalah bagaimana pengaturan hukum kejahatan dan pelanggaran penyalahgunaan hak kebebasan berpendapat di media social dan bagaimana sanksi pidana terhadap tindak pidana pencemaran nama baik berkedok kebebasan berpendapat dengan. Metode penelitian yang digunakan adalah penelitian hukum normative. Sumber bahan hukum primer dan sekunder. Penelitian ini menyimpulkan bahwa kebebasan dalam berpendapat bukan merupakan kebasan yang sifatnya mutlak, melainkan dalam berpendapat harus sesuia dengan etika dan norma-norma di masyarakat dan sesuai dengan pengaturan hukum tanpa merugikan pihak manapun. Dan perbuatan tidak menyenangkan tersebut dapat dituntut sesuai ketentuan hukum yang berlaku.
\end{abstract}

Kata Kunci: Aturan; Kebebasan Berpendapat; Tindak Pidana

\section{Pendahuluan}

Media sosial merupakan media yang memfasilitasi penganutnya untuk melakukan interaksi antar sesama pengguna tanpa perlu memperhatikan jarak antar sesama pengguna tersebut. Media social ada berbagai macam, sehingga masyarakat dapat memilih dan mengakses media sosial sesuai dengan apa yang mereka mau dan memanfaatkannya untuk melakukan interaksi sosial.

Interaksi social yang dilakukan di media social menjadi lebih terbuka dan lebih privat antara sesame pengguna, karena hal tersebut seringkali masyarakat lupa akan norma-norma keseponan dalam melakukan interaksi social. Media social juga dijadikan wadah dalam penyampaian pendapat oleh masyarakat, namun dalam penyampaian pendapat tersebut perlu kehati-hatian dan memperhatikan norma-norma kesopanan dalam penyapaian kritik atau pendapat kepada pihak-pihak tertentu sehingga tidak minumbulkan tindak pidana pencemaran nama baik (Suhariyanto, 2014). 
Rendahnya tingkat kesadaran masyarakat dalam memilih konten-konten positif di sosial media menyebabkan banyaknya informasi yang belum tentu kebenarannya berkembang dalam masyarakat, hal tersebut dapat memancing masyarakat dalam melakukan kritik dan kritik yang dilakukan seringkali melanggar normanorma kesopanan dan kritik tersebut menimbulkan perbuatan hukum yang harus ditanggung oleh masyarakat yang melakukan kritik terhadap informasi tersebut (Simarmata, 2019).

Mengutip informasi di media bahwa Mendagri mengatakan kebebasan berpendapat di muka umum maupun kebebasan berserikat dan berkumpul itu sifatnya tidak mutlak. Dalam kebebasan tersebut tetap ada batasan dimana harus menghargai hak-hak asasi orang lain, harus menjaga ketertiban umum dan publik, harus memperhatikan etika, norma dan moral, harus menjaga tata bahasa dalam penyampaian pendapat.

Banyaknya kasus terkait pencemaran nama baik, penyebaran berita hoaks khususnya melalui media social, hal tersebut menjadi bukti bahwa masyarakat kita masih belum sadar akan batasan-batasan dalam melakukan kegiatan di social media. Masyarakat tidak menyadari bahwa perbuatan tertentu yang mereka lakukan dapat menimbulkan kerugian bagi pihak tertentu, kerugian tersebut dapat berupa kerugian materiil maupun kerugian atas pencemaran nama baik.

Tindak pidana pencemaran nama baik di media sosial tersebut terjadi dikarenakan kurangnya kehati-hatian dari masyarakat itu sendiri dalam melakukan kegiatan di media sosial, kegiatan tersebut dapat berupa mengunggah sebuah tulisan, mengunggah sebuah foto, video, mengunggah sebuah informasi yang belum tentu kebenarannya dan atas ketidak hati-hatian tersebut berakibat akan bersinggungan dengan nama baik orang lain, kelompok maupun instansi-instansi tertentu.

Dalam Kitab undang-Undang Hukum Pidana memuat bahwa seseorang dapat dinyatakan melakukan atau mencemarkan nama baik apabila seseorang tersebut sengaja bertujuan untuk menyampai kan kritik yang berkaitan dengan kehormatan, kedudukan, martabat atas nama baik seseorang yang diketahuinya. Kitab Undang- Undang Hukum Pidana menyuraikan bahwa delik aduan atas pencemaran nama baik tercantum dalam Bab XVI pasal 321 KUHP.

Jika melihat pemaparan dari KUHP, pencemaran nama baik dikategorikan sebagai penghinaan dan penistaan terhadap seseorang. Penghinaan tersebut dilakukan dengan cara melayangkan tuduhan kepada seseorang bahwa orang tersebut telah melakukan perbuatan tertentu dengan maksud dari tuduhan tersebut agar informasi mengenai tuduhan tersebut diketahui oleh umum (orang banyak).

Perkembangan teknologi dan informasi memberikan wadah bagi masyarakat dalam melakukan komunikasi tanpa memikirkan jarak dari lawan komunikasinya. Pemanfaatan atas teknologi komunikasi dan informasi, secara tidak langsung perubahan tersebut telah memberikan dampak dalam perubahan perilaku masyarakat maupun kehidupan manusia dalam bersosialisasi dengan masyarakat lainnya tanpa ada jarak yang membatasi nya.

Interaksi sosial yang dilakukan di media sosial menjadi lebih terbuka dan lebih privat antara sesama pengguna, karena hal tersebut seringkali masyarakat lupa akan norma-norma kesopanan dalam melakukan interaksi sosial. Media sosial juga dijadikan wadah dalam penyampaian pendapat oleh masyarakat, namun dalam penyampaian pendapat tersebut perlu kehati-hatian dan memperhatikan norma-norma kesopanan dalam penyampaian kritik atau pendapat kepada pihak-pihak tertentu sehingga tidak minumbulkan tindak pidana pencemaran nama baik.

Pada dasarnya setiap manusia memang bebas dalam berpendapat, namun kebebasan berpendapat tersebut harus bisa dipertanggungjawabkan dan sesuai dengan aturan perundang-undangan yang berlaku. Jika penyampaian pendapat tersebut tidak disertai dengan dasar penyampaian yang jelas dan tidak didasari akan rasa tanggung jawab, maka kebebasan berpendapat itu sendiri dapat menyebabkan kerugian bagi pihak tertentu baik itu kerugian materiil atau kerugian atas pencemaran nama baiknya.

Dalam penyampaian pendapat tidak boleh dilakukan secara anarki. Yang dimaksud tindakan anarki adalah tindakan kekerasan yang dapat berupa pengrusakan fasilitas umum. Oleh karena itu, mengemukakan pendapat harus diatur dalam suatu peraturan yang mana didalamnya harus berisi mengenai batasanbatasan kesopanan dalam penyampaiannya dan berisi sanksi atau hukuman apabila melanggar ketentuan tersebut.

Sebelum adanya perkembangan teknologi yang menghasilkan media social, pada dasarnya penyampaian pendapat dilakukan secara 
langsung di muka umum melalui pidato, dialog, diskusi. Namun kebebasan dalam penyampaian pendapat tersebut harus sesuai dengan ketentuan dalam peraturan perundang-undangan agar tidak menimbulkan konflik dalam penyampaiannya.

Berdasarkan pada uraian diatas, maka dapat ditemukan rumusan masalah yang akan dibahas, yaitu 1) Bagaimana pengaturan hukum kejahatan dan pelanggaran penyalahgunaan hak kebebasan berpendapat di media sosial? Dan 2) bagaimana sanksi pidana terhadap tindak pidana pencemaran nama baik berkedok kebebasan berpendapat?

Tujuan penelitian dalam penulisan ini adalah tujuan penelitian yang bersifat umum dan tujuan penelitian yang bersifat khusus. Tujuan yang bersifat umum, yaitu 1) sebagai pemenuhan tugas dalam memperoleh gelar Sarjana Hukum di Universitas Warmadewa. 2) sebagai bentuk kontribusi pemikiran yang dapat berguna bagi pihak- pihak tertentu. 3) sebagai salah satu sarana dalam penerapan ilmu hukum yang telah didapat selama masa perkuliahan.

Tujuan yang bersifat khusus, yaitu 1) mengetahui penerapan hukum atas kejahatan dan pelanggaran penyalahgunaan hak atas kebebasan berpendapat. 2) antisipasi dalam penyampaian pendapat sehingga terhindar dari pencemaran nama baik dan menggunakan hak kebebasan berpendapat di media social secara bijak.

\section{Metode}

Penelitian ini termasuk kedalam penelitian hukum normatif, yang dikaji menggunakan studi kepustakaan yang berupa bahan-bahan hukum dan berdasar pada norma-norma yang ada. Pendekatan masalah yang digunakan dalam penelitian ini adalah pendekatan perundangundangan dan pendekatan konseptual yang menekankan pada pandangan dan doktrindoktrin yang berkembang dalam ilmu hukum.

Teknik pengumpulan bahan hukum yang digunakan adalah bahan hukum primer yang didapat dengan menganalisis peraturan perundang-undangan, risalah resmi, dan beberapa keputusan-keputusan yang menyangkut dengan judul tulisan ini. bahan hukum sekunder didapat dari menganalisis buku-buku, jurnal-jurnal dan hasil- hasil penelitian terdahulu yang memiliki keterkaitan dengan judul penulisan ini. Dan bahan hukum tersier yang dapat menunjang bahan hukum primer dan sekunder seperti kamus-kamus hukum dan tulisan yang dapat diakses melalui internet.

Bahan-bahan yang diperoleh kemudian dianalisis menggunakan teknik interpretasi, yang dimana teknik ini mengedepankan analisa dengan memaparkan pola- pola deskriptif, mencari keterkaitan antara deskripsi-deskripsi yang ada dengan memilih bahan-bahan yang dapat menjawab permasalahan dalam tema penulisan ini, serta disajikan dalam bentuk deskriptif analitis yang memberikan gambaran secara jelas mengenai permasalah penulisan ini secara sistematis sehingga dapat diperoleh kesimpulan akan tema penulisan ini.

\section{Hasil Dan Pembahasan}

\section{Pengaturan Hukum Kejahatan dan Pelanggaran Penyalahgunaan Hak Kebebasan Berpendapat di Media Sosial}

Kebebasan dalam mengemukakan pendapat merupakan hak dari setiap warga negara Indonesia. Hak dan kewajiban dalam kebebasan berpendapat tersebut diatur dalam Batang Tubuh UUD 1945 pasal 28 dan UU No. 9 Thn 1998 Tentang Kemerdekaan dalam penyampaian pendapat di muka umum, kebebasan dalam berpendapat itu sendiri tidak dapat dipisahkan dengan hak untuk berkumpul, protes, dan menuntut akan adanya perubahan (Nurdiaman, 2007).

Pada saat ini perkembangan teknologi di bidang informasi dan komunikasi sangatlah pesat. Perkembangan teknologi tersebut dimanfaatkan masyarakat dalam hal penyampaian informasi, berpendapat ataupun berekspresi akan keseharian mereka, namun, dalam penggunaannya diperlukan kehati-hatian, karena bisa saja pendapat dan informasi yang kita sebarkan berbenturan akan kehormatan dan kepentingan orang lain, hal tersebut dapat berakibat pada tindak pidana pencemaran nama baik.

Kebebasan berkumpul dan kebebasan dalam menyampaikan pendapat diatur dalam dalam pasal 28, 28E, 28F UUD 1945. Pasal 28F menyatakan bahwa setiap individu berhak untuk berkomunikasi dan memperoleh informasi baik untuk kebutuhan pengembangan dirinya sendiri dan lingkungan sosialnya dan berhak untuk mencari, memperoleh, memiliki, menyimpan informasi yang didapat melalui media elektronik.

Hak atas kebebasan dalam penggunaan media teknologi khususnya dalam hal informasi dan komunikasi dilakukan dengan mempertimbangkan Batasan-batasan yang telah 
diatur dalam UU dengan tujuan untuk menjamin pengakuan serta penghormatan atas hak dan kebebasan dari orang lain dan untuk memenuhi tuntutan atas petimbangan moral, norma-norma dalam masyarakat, nilai agama dan ketertiban umum dalam suatu masyarakat yang demokratis (Bungin, 2018).

Dengan berkembagnya teknologi khusunya dalam hal informasi dan komunikasi, media sosial menjadi sarana bagi pelaku tindak kejahatan. Kemajuan informasi dan komunikasi menimbulkan dampak berupa perubahan mendasar dan luas dalam hal penyampaian informasi. Mengingat sekarang setiap orang bisa mengakses informasi sesuai dengan kemauan mereka dan tidak ada Batasan dalam menanggapi sebuah berita ataupun informasi yang didapat, oleh karena itu menyebabkan sering terjadinya tindak pidana pencemaran nama baik di sosial media atau media informasi dan komunikasi lainnya.

Undang-Undang No 11 Tahun 2008 Tentang Informasi dan Transaksi elektronik merupakan Undang-Undang pertama yang didalamnya mengatur tentang Teknologi Informasi dan Komunikasi sebagai salah satu produk legislasi yang sangat dibutuhkan dan telah menjadi acuan yang meletakkan dasar pengaturannya di bidang pemanfaatan informasi dan transaksi elektronik itu sendiri.

Ujaran kebencian merupakan ucapan atau ekspresi yang bersifat verbal maupun nonverbal yang ditujukan untuk merendahkan seseorang, menindas atau melakukan publikasi atas kekerasan terhadap seseorang atas dasar keanggotaan atau keikutsertaan mereka dalam suatu kelompok organisasi sosial ataupun etnis, kebencian tersebut melibatkan lebih dari sekedar menunjukan bahwa anda tidak menyukai seseorang.

Pencemaran nama baik melalui media sosial merupakan tindakan yang dilakukan oleh seseorang ataupun oknum yang menyebarkan fitnah atau tuduhan yang tidak didasari dengan kebenaran akan tuduhan tersebut, baik berupa ucapan, foto, video, serta dapat menyerang kehormatan seseorang dan nama baik seseorang dan menimbulkan rasa malu bagi pihak yang ditujukan atas ujaran tersebut.

Dalam penyampaian pendapat tidak boleh dilakukan secara anarki. Yang dimaksud tindakan anarki adalah tindakan kekerasan yang dapat berupa pengrusakan fasilitas umum. Oleh karena itu, mengemukakan pendapat harus diatur dalam suatu peraturan yang mana didalamnya harus berisi mengenai batasan- batasan kesopanan dalam penyampaiannya dan berisi sanksi atau hukuman apabila melanggar ketentuan tersebut.

Perkembangan teknologi telah mempengaruhi banyak aspek kehidupan dari masyarakat itu sendiri. Salah satu aspek tersebut adalah perkembangan dalam dunia kejahatan. Perkembangan teknologi beriringan dengan perkembangan tindak kejahatan dalam masyarakat sehingga munculnya tindak kejahatan baru yang belum pernah terjadi sebelumnya. Salah satu dampak dari perkembangan teknologi itu sendiri adalah tindak kejahatan atas pencemaran nama baik yang bisa terjadi dikarenakan terlalu mudahnya mengakses dan melakukan kritik terhadap suatu informasi.

\section{Sanksi Hukum Terhadap Tindak Pidana Pencemaran Nama Baik Berkedok Kebebasan Berpendapat}

Hukum pidana merupakan hukum yang mengikat kepada suatu perbuatan tertentu yang memenuhi syarat-syarat tertentu sebagai suatu akibat dari perbuatan yang ditimbulkan berupa perbuatan pidana. (Kasiyanto, 2018). Di Dalam hukum pidana terdapat suatu perbedaan, yaitu hukum pidana itu sendiri yaitu didalamnya mengenal adanya suatu kesengajaan yang memberikan suatu sebab akibat berupa suatu penderitaan bagi pelaku nya dalam bentuk hukuman berupa hukuman kurungan, denda dan hukuman mati apabila tindak pidana yang dilakukan tergolong ke tindak pidana kelas berat.

Arah dari perkembangan tindak kejahatan itu sendiri sangatlah pesat dan tidak bisa ditebak. Upaya yang ditempuh pemerintah guna mengatasi tindak kejahatan tersebut adalah melalui beberapa bidang, yang diantaranya adalah bidang politik, ekonomi, Pendidikan dan beberapa bidang lainnya.

Mengatasi kejahatan melalui beberapa aspek tersebut diharapkan lebih berdampak ketimbang hanya menggunakan kebijakan yang memiliki keterbatasan akan kemampuan hukum pidana, yaitu sebab-sebab dari terjadinya suatu kejadian sangatlah kompleks, hukum pidana hanya merupakan bagian dari sarana kontrol sosial guna mengatasi kejahatan sebagai masalah utama dalam kehidupan bermasyarakat.

Penggunaan hukum pidana itu sendiri dalam menanggulangi kejahatan hanya sebatas penanggulangan gejala dari kejahatan itu 
sendiri. Dan atas perbuatan pidana tersebut, pelaku tindak pidana harus mendapat sanksi pidana yang berupa hukuman kurungan denda dan bahkan hukuman mati apabila perbuatan pidana yang dilakukan tergolong ke dalam tindak pidana berat. Dan dari ketiga sanksi tersebut hukum pidana juga masih dikatakan memiliki keterbatasan akan sanksi nya dalam memberikan efek jera bagi pelaku tindak kejahatan.

Meskipun ada beberapa kekurangan seperti pemaparan diatas, pidana dan pemidanaan itu sendiri tetap menarik karena begitu banyak peraturan perundang- undangan yang mengatur mengenai pidan itu sendiri. Dengan banyaknya pengaturan yang mengatur mengenai pidan itu sendiri, tetapi pengaturan utama atau pokok yang mengatur mengenai pidan adalah Kitab Undang-Undang Hukum Pidan (KUHP).

Kebebasan berkumpul dan kebebasan dalam menyampaikan pendapat diatur dalam dalam pasal 28, 28E, 28F UUD 1945. Pasal 28F menyatakan bahwa setiap individu berhak untuk berkomunikasi dan memperoleh informasi baik untuk kebutuhan pengembangan dirinya sendiri dan lingkungan sosialnya dan berhak untuk mencari, memperoleh, memiliki, menyimpan informasi yang didapat melalui media elektronik.

Penghinaan sudah lama menjadi bagian dari hukum pidana itu sendiri. Pada dasarnya sampai saat ini Indonesia masih mewarisi dan menggunakan sistem hukum Hindia Belanda. Pada dasarnya hukum penghinaan di Indonesia diatur menjadi dua kelompok, yaitu kelompok hukum pidana itu sendiri dan kelompok hukum perdata. Dan dalam kedua pengaturan hukum tersebut termuat beberapa pasal yang mengatur mengenai penghinaan.

Pencemaran nama baik yang dilakukan di media sosial sudah termasuk kedalam delik pidana. Dapat dijerat dengan pasal atas penghinaan individu dan atas penghinaan nama baik, sesuai dengan yang tertuang dalam Kitab Undang-Undang Hukum Pidana. Pelaku dari tindak pidana pencemaran nama baik menimbulkan kerugian moril dan materiil bagi salah satu pihak, dan atas dasar tersebut makan pelaku tindak pidana pencemaran nama baik dapat dipidana.

\section{Simpulan}

Pengaturan Mengen tindak pidana atas penyalahgunaan dari hak kebebasan berpendapat di media sosial diatur dalam UU No, 11 Thn 2008. Yang dimana dalam UU tersebut memaparkan mengenai hak dan kebebasan melalui penggunaan dan pemanfaatan teknologi itu sendiri harus dilakukan dengan mempertimbangkan pembatasan dari ketentuan Undang-Undang dan memperhatikan kepentingan orang dalam penyampaian pendapar di media sosial. Undang -Undang ini diharapkan agar dapat menjamin pengakuan dan penghormatan dari setiap warga negaea atas Batasan terhadap kebebasan dalam berekspresi di media sosial agar tidak merugikan individu tertentu ataupun kelopok dan organisasi tertentu.

Sanksi pidana terhadap tindak pidana pencemaran nama baik telah ditetapkan dalam KUHP terutama dalam pasal 310 ayat (1) yang dimana didalamnya berisikan ketentuan hukum bagi para pelaku tindak pidana pencemaran nama baik, hukumannya berupa kurungan penjara selama 9 bulan dan denda yang harus dibayarkan sebesar empat ribu lima ratus rupiah. Dan jika tindak pidana pencemaran nama baik tersebut dilakukan di media sosial maka dapat dituntut melalui Undang-Undang No 11 Tahun 2008 Tentang Informasi dan Transaksi Elektronik pada pasal 45 ayat (3) dengan ancaman kurungan selama 6 tahun penjara dan denda sebesar satu miliar rupiah.

Sebaiknya UU No. 11 Thn 2008 perlu dilakukan revisi atau perbaikan terutama dalam pasal-pasal yang menyangkut mengenai penghinaan dan pencemaran nama baik di media sosial, dikarenakan banyak pasal yang memiliki makna ganda didalamnya.

\section{Daftar Pustaka}

Bungin, B. (2018). Komunikasi Politik Pencitraan. Jakarta: Prenada Media.

Kasiyanto, A. (2018). Teori dan Praktik Sistem Peradilan Tipikor Terpadu di Indonesia. Jakarta: Prenada Media.

Nurdiaman, A. (2007). Pendidikan Kewarganegaraan Kecakapan Berbangsa dan Bernegara. Jakarta: Pribumi Mekar.

Simarmata, J. (2019). Hoaks dan Media Sosial. Jakarta: PT Raja Grafindo Persada.

Suhariyanto, B. (2014). Tindak Pidana Teknologi Informasi. Jakarta: PT Raja Grafindo Persada. 